\title{
Pharmaceuticals and Dietary Supplements Extracted from Mare's Milk
}

\author{
Anca Alexandra STUPARU*, Crina Elena STRUGARIU, Teofil OROIAN \\ University of Agricultural Sciences and Veterinary Medicine, Faculty of Animal Science and \\ Biotechnologies, 3-5 Manastur Street, 400372 Cluj-Napoca, Romania, \\ * corresponding author, e-mail: ancalexandra.stuparu@gmail.com
}

Bulletin UASVM Animal Science and Biotechnologies 73(1)/ 2016

Print ISSN 1843-5262; Electronic ISSN 1843-536X

DOI:10.15835/buasvmcn-asb: 11429

\begin{abstract}
Mare's milk is similar to human breast milk and has valuable therapeutic properties. For this reason, Europeans are increasingly interested in discovering its benefits and how the chemical composition of horse milk differs from that of other species. This interest is reflected in the number of new farms selling mare's milk around the world as this milk is the most similar to human milk. Mare's milk is considered to be highly digestible, rich in essential nutrients and whey protein, which makes it very suitable as a substitute for bovine milk in paediatric diets. During the period of lactation, mammal's milk composition is subject to rapid changes in macro- and micro-elements, as well as in the quantity and quality of proteins, lipids and saccharides, being ideal food for infants. The primary use of mare's milk has been the rearing of foals, but recently, due to the similarity of its chemical composition to that of human milk, it has raised particular interest and some experiments have been done to apply it as a raw material for the preparation of special food products for human consumption. Mare's milk products are very common in Russia and Central Asia throughout Mongolia. In the $19^{\text {th }}$ century, some Russian scientists explored its therapeutic properties and then in 1859 they founded the first sanatorium where treatments with mare's milk could be made under medical control. Due to its potential health-promoting characteristics, in the Western countries, interest in mare's milk has lately increased.
\end{abstract}

Keywords: chemical composition, equine milk, horse, mare's milk

\section{INTRODUCTION}

The two domestic equine species - horse and donkey - belong to the order Perissodactyla, family Equidae, genus Equus. According to Herodotus, horses (Equus caballus) were traditionally milked in Central Asia and Eastern Europe (Salimei, 2012). D'Arval reports that in the nineteenth century, donkey milk was successfully used for feeding orphaned infants in France. In the last several years, horse colostrums and milk production developed in France (Drogoul et al., 1992, Malacarne et al., 2002), Chevalait (Nature Progress), the European leader in the production of horse milk.

Milk is created by nature to nourish; the protein that is found in milk is specific to the species. Milk is destined to feed the newborn, and it contains components which are responsible for homeostasis and health (Gopal et al., 2000, Kunz et al., 2006).

In this review paper, we draw a parallel between the composition of mare's, human and cow's milk, considering protein fractions and fatty acid content. The quantity of fat in mare's milk is lower as compared to human milk or cow's milk; the content of protein is higher than in human milk and lower than in cows' milk.

The aim of this review is to analyse the composition of mare's milk and to compare it with human and cow's milk, and also to discuss parameters that could be of interest for the human food industry and cosmetic industry. The paper also provides a bibliographic study on the latest 
European mare's products on the market: dietary supplements and cosmetological products.

\section{Mare's milk composition and uses in human nutrition}

Secretion of mammary gland in terms of milk composition is physiologically and structurally correlated to the nutritional requirements of the newborns of each species (Potočnik et al., 2011). For this reason in nature each species drinks only its own milk. Mare's milk shows some structural and functional characteristics that make it more suitable for human nutrition than cow's milk.

In western European countries, studies have been focused mainly on the growth and health of newborn horses (Malacarne at al., 2002), but due to similarity with human milk, lately interest has increased in the use of mare's milk for human nutrition particularly in France, Germany (Drogoul et al., 1992), Italy and Belgium. Mare's milk has recently been studied in Italy as well, as a possible substitute for cow's milk or as formulas for allergic children (Businco et al., 2000; Curadi et al., 2001). In Belgium, we see the start of production of small refrigerated mare's milk bags as an alternative for allergic children formulas.

Interestingly, apart from being the most important nutritional resource for foals during the first months of life, mare's milk is also one of the most important basic foods for human populations in Central Asia, where a fermented lactic alcoholic beverage called koumiss is traditionally consumed - this is considered a beverage with healthpromoting properties (Uniacke-Lowe, 2011). This drink is currently produced on an industrial scale in Eastern Europe and Asia (Orlandi et al., 2003). The results of recent studies in Europe triggered the appearance of a large number of mare's milk products intended for human consumption.

Milk of all mammals has the same chemical composition, being composed of the same organic substances: protein, fat, lactose vitamins and minerals. The differences between the species are given by the fact that all these substances vary in quantitative terms.

\section{Milk protein fractions}

As concerns protein, mare's and human's milk is poorer when compared to cow's milk. The whole protein system of mare's milk is quite similar to that of human milk (Malacarene et al.,
2002). Cow's milk has a higher casein content, and is thus defined as a caseineux milk (Alais, 1974; Mariani et al., 1993).

The whey protein fraction, indeed, represents approximately $40 \%$ in mare's milk, slightly more than $50 \%$ in human milk and less than $20 \%$ in cow's milk. Cow's milk protein features, like other ruminant milk (e.g. goat and sheep), are quite different, as characterised by an acid-enzymatic, mixed coagulation. From this point of view, mare's milk is more similar to human milk, which could be defined typically as albumineux. The richness in whey protein content of mare's milk makes it more favourable to human nutrition than cow's milk, because of the relatively higher supply of essential amino acids (Hambræus, 1994).

As stated above, casein is the predominant class of proteins in bovine milk, but in equine milk there are less caseins and more whey proteins: $\beta$-Lg (beta lactoglobulin), $\alpha$-La (alpha lactalbumin), Igs (imunoglobulins), BSA (blood serum albumin), Lf (lactoferin) and Lyz (lyzozyme). Antimicrobial defence in mare's milk seems to be due mainly to the presence of lysozyme (as in human milk) and, to a lesser degree, to lactoferrin, which is preponderant in human milk (Solaroli et al., 1993). These antimicrobial factors are scarce in cow's milk, where immunoglobulins represent the principal defense against microbes and are particularly abundant in colostrum (Boland et al., 1992; Solaroli et al., 1993).

All these proteins are present in human milk as well, except $\beta$ - $\mathrm{Lg}$, which is not. The richness in whey protein content of mare's milk makes it more favourable to human nutrition than cow's milk, because of the relatively higher amount of essential amino-acids (Hambræus, 1994). Whole protein and salt content are comparable between mare and human milk, while cow's milk is clearly richer in salts, and thus less suitable as a replacement for human milk (Malacarene et al., 2002). From these several considerations on the gross composition, mare's milk would appear to be, on the whole, a more suitable nourishment for infants than cow's milk (Marconi and Panfili, 1998).

\section{Milkfat}

Mare's milk has noticeably less fat content. The fat content of horse milk is remarkably lower than the fat content of human and ruminant milk, which is also reflected by their calorific value. 
Lipids in milk are dispersed as emulsified globules; in mare's milk, fat is organised in globules of about 2-3 $\mu \mathrm{m}$ in size (Kharitonova, 1978; Welsch et al., 1988). Fat globules are coated with three layers: an internal protein layer, an intermediate layer consisting of a phospholipid membrane and the external layer consisting of high-molecularweight glycoproteins. On the surface of these glycoproteins there is a branched oligosaccharide structure, which is similar to that of the fat globules in human milk and which is not found in cow's milk (Solaroli et al., 1993).

Horse and donkey milk fat consists of $80-85 \%$ triglycerides, $9.5 \%$ free fatty acids and $5-10 \%$ phospholipids. Bovine, sheep, goat and human milk fat consists of $97-98 \%$ triglycerides, but has only low levels of phospholipids (0.5-1.5\%) and free fatty acids (0.7-1.5\%) (Doreau et al., 2002; Malacarne et al., 2002; Park et al., 2007; Uniacke-Lowe, 2011). Compared to ruminants, horse and donkey milk fat contains a higher percentage of polyunsaturated fatty acids (PUFA) and a lower percentage of saturated fatty acids (SFA) and monounsaturated fatty acids (MUFA). The fatty acids of horse and donkey milk are mainly unsaturated or short-chained, which is interesting from a nutritional point of view. For instance, polyunsaturated fatty acids (linoleic and linolenic) in mare and human milk are remarkably higher than in cow's milk. (Akai et al., 2014, Macharadze, 2007). Horse milk contains about 10 times more caprylic acid (C8:0), 3 times more capric acid (C10:0) and twice more lauric acid (C12:0) than bovine milk. Horse and donkey milk has additionally higher levels of linoleic acid and $\alpha$-linolenic acid than bovine milk ( 5 and 224 times more, respectively) (Salamon et al., 2009. Some positive health effects are attributed to CLA (conjugated linoleic acids) isomers such as lowering the risk of cardiovascular diseases, carcinogenesis, diabetes and osteoporosis, and modulation of the immune system (Barlowska et al., 2011; Uniacke-Lowe, 2011). The presence of trans fatty acids in horse milk suggests some fatty acid hydrogenation by intestinal microorganisms before absorption (Hoffman et al., 1998). Besides the composition of milk fat, the distribution of fatty acids on the glycerol backbone also needs to be considered, as it determines the lipolysis and thus bioavailability of fatty acids and, therefore, their possible beneficial or detrimental effects on health (German and Dillard, 2006). The milk of most of the considered ruminants contains a similar cholesterol level as human milk, whereas the cholesterol level of horse and donkey milk appears to be much lower. Cholesterol is mostly associated with cardiovascular diseases, but is also an important component of body cell membranes and of the central nervous system (Dietschy and Turley, 2004; Gidding et al., 2006). It has been suggested that human milk cholesterol may be responsible for long-term regulation of cholesterol metabolism and myelin synthesis, although results are not univocal (Gidding et al., 2006; Schanler, 2011).

\section{Milksugars}

Lactose is quantitatively the main milk sugar. Its concentration is similar in horse, donkey and human milk, but lower in bovine or other ruminant milk. Other milk carbohydrates, which are free or bounded to lipids, proteins or phosphate, include a small fraction of oligosaccharides. They are composed of galactose, fucose, $\mathrm{N}$-actylglucosamine and/or $\mathrm{N}$-acetyl neuramic acid (sialic acid) and contain mostly a lactose unit at their reducing end. They have the potential to modulate the growth of intestinal flora, to influence different gastro-intestinal and inflammatory processes and to provide protection against bacterial and viral infections (Kunz and Rudloff, 2006). In general, the oligosaccharide level is much lower in animal milk compared to human milk (Abd El-Salam and ElShibiny, 2011; Martinez-Ferez et al., 2006; Mehra and Kelly, 2006). No data were found in literature on the oligosaccharide level of horse milk, but it is probably much lower than the level of horse colostrum. The latter is reported to contain 18.6 $\mathrm{g} / \mathrm{l}$ oligosaccharides compared to $20 \mathrm{~g} / \mathrm{l}$ in human colostrum (Nakamura et al., 2001; Uniacke-Lowe, 2011). Oligosaccharide-bound sialic acid (but also glycoprotein-bound and free sialic acid) is reported to affect the intestinal flora development and, most probably, the level of glycosylation of gangliosides of the brain and the central nervous system (Malacarne et al., 2002; Potocnik et al., 2011). Sialic acid levels measured in human milk (1 g/l) are significantly higher than the levels measured in bovine or horse milk (around 0.05$0.2 \mathrm{~g} / \mathrm{l}$ ) (Malacarne et al., 2002; Potocnik et al., 2011). During heating, only a small fraction of lactose is converted into lactulose (around 0.5\% 
during UHT treatment and $1-2 \%$ by sterilization). Lactulose has, similarly to lactose, prebiotic properties (Schaafsma, 2002).

Mare's milk is rich in lactose $(64 \mathrm{~g} / \mathrm{kg}$ ) (Di Cagno et al., 2004). The average content is 6.26\%, which means it is much higher than in cow's, goat's, or sheep's milk. Because of the high content in lactose, mare's milk has a sweeter taste than the other types of milk considered for human consumption. Because most of the populations in Asia are affected by lactose malabsorption, mare's milk is rather used as fermented milk - koumiss (Eastern Europe), airag (Mongolia) or chigee (Mongolia, China) (Čagalj et al., 2014). The lacticalcoholic beverage derived from horse milk is the combination of raw milk and indigenous microbial populations: lactic acid bacteria and yeast whose diversity is of increasing interest (Batdorji et al., 2006; Di Cagno et al., 2004; Watanabe et al., 2008). The microflora found in mare's milk consists mostly of Lactobacillus sp. and Lactococcus sp., and yeasts such as Saccharomyces unisporus (Di Cagno et al., 2004). Bacteria called Bifidobacterium mongoliense sp. nov. and Lactobacillus casei Zhang have been lately isolated from airag.

\section{Milk vitamins}

The total vitamin content of milk is highly variable and depends on the vitamin status and the feeding regime of the mother (with the level of water-soluble vitamins being more influenced by the feed than the level of the fat-soluble vitamins). The vitamin content of horse milk is on average lower than the vitamin content of ruminant milk. An exception is the vitamin $\mathrm{C}$ level, which is relatively high in horse milk (Doreau et al., 2002;). Additionally, it is noted that sheep, goat and buffalo milk have a higher vitamin A content than bovine milk. Their milk is whiter than other milk due to the ability to convert the yellow b-carotene to vitamin A (Abd El-Salam et al., 2011; Jainudeen, 2002; Park et al., 2007).

\section{Milk minerals}

As for the content of essential macro minerals in mare's milk: $\mathrm{Ca}$ and $\mathrm{P}$ concentrations are 3 times higher than in human milk and twice lower than in cow milk (Gaucheron, 2005). K, Na, and Mg concentrations in equine milk are similar to those in human milk, and they vary significantly during lactation (Fantuz et al., 2011, Summer et al., 2004).
Milk is mainly a good source of calcium (Ca) and phosphorus (P), which are necessary for bone growth, development, metabolism and maintenance (Adolphi et al., 2009; Cashman, 2006), but is less important with respect to the other minerals. Bovine milk contains about 50\% more Ca and twice as much $\mathrm{P}$ and potassium (K) than horse and donkey milk, but horse and donkey milk contains about 2-3 times more Ca and P than human milk (Anderson, 1991; Csapó et al., 2009; Salimei and Fantuz, 2012).

\section{Mare's milk products with therapeutic effect}

This paper shows a comparison between human milk, cow's milk and equine milk and highlights the importance of equine milk in terms of human nutrition and treatment. The assessment of these three sources of milk nutrients indicating that the mare's milk could be used as a substitute for allergic children instead of cow's milk or in special anti-allergic formulas. In countries such as Belgium, Germany, France or Italy, mare's milk is sold instead of breast milk or instead of powdered milk formulas for newborns, or simply for winter immunization cures - packages for 3 to 6 month cures, are sold on farms or bio-shops. Horse milk has been used successfully as an alternative food for infants with allergies, e.g. cow's milk protein allergy (CMPA), a common food allergy in childhood with a prevalence of approximately 3\% during the first 3 years of life (Salimei, 2012). Milk allergy is the most common childhood allergy. Although cow's milk is the one that causes most cases of allergy, other milks such as sheep, goat or buffalo milk can also cause an allergic reaction. About horse milk, it is known that its composition differs from the milk of other species (Park et al., 2007; Pulina and Nudda, 2002).

Raw horse milk and fermented derivative products seem to be very useful in the prevention of cardiovascular disorders. Koumiss, which is rich in angiotensin converting enzyme (ACE)inhibitory peptides, supports the assertion that its effects are beneficial on cardiovascular health (Chen et al., 2010). Mare milk is also able to regulate the immune response and anti-tumoral activity (Mao et al. 2009).

Mare's milk comes to be rated for its medicinal properties. Products based on mare's milk are used in the food, cosmetic and pharmaceutical 
industry: koumiss and cosmetic products are already well known, and then the pharmaceutical treatments for chronic gastric ulcer disease, tuberculosis, dysentery, scurvy, and other chronic diseases (Solaroli et al., 1993) started to be more and more popular.

For people with skin diseases, stomach and intestinal troubles, horse milk seems to have a positive influence. Horse milk is recommended for metabolism problems, Crohn's disease and ulcerative colitis, psoriasis, multiple sclerosis, fibromyalgia, high cholesterol value, stiff joints, menopause symptoms and cancer.

Many diseases originate because of an unbalanced gut flora. A disturbed intestinal flora leads to vitamin deficiencies and general weakness. Bad bacteria produce toxic residues, which irritates the guts and will be transferred into the bloodstream. The irritation of the intestines can cause diarrhoea or constipation, which leads to flatulence, rumbling bowels, increased stomach acid production and nausea. The impact of absorbing toxic residues in the blood can lead to exhaustion, weariness, headaches, liver overload, and even forms of eczema, psoriasis, bronchitis and asthma. Horse milk stimulates the increase of good bacteria in the bowel flora, which results in the fact that bad bacteria cannot multiply. In this way, the absorption of toxic substances in the bloodstream will decrease. The microflora found in mare's milk consists mostly of species like Lactobacillus delbrueckii ssp. bulgaricus, Lactococcus lactis ssp. lactis, Kluyveromyces fragilis and Saccharomyces unisporus (Di Cagno et al., 2004). Bacteria called Bifidobacterium mongoliense sp. nov. have been lately isolated from airag (Watanabe et al., 2009) and Lactobacillus casei Zhang started to be investigated in 2009 (Guo et al., 2009) and in early 2012, Zhang confirmed the influence of this second newly discovered bacterium isolated from airag, in reducing highcholesterol (Zhang et al., 2012). Probiotics defined as "living microorganisms, which upon ingestion in certain numbers, exert health effects beyond inherent basic nutrition" (Guarner and Schaafsma, 1998), are very much used in nutritional supplements, pharmaceuticals and functional foods (Del Piano et al., 2006). Probiotics suppress the growth of bad bacteria in the colon and small intestine, thus stabilizing the digestive system, microflora, and the intestinal saprophyte environment. Also, they have anti-tumoral activity, and improve the lactose utilization in the human gut (Kailaspathy and Rybka, 1997).

Results from recent research across Europe have indicated that therapeutic effects of mare's milk can be explained by a high content of phospholipids and vitamin A (Park et al., 2008).

Skin problems: The use of mare's milk is most definitely recommended for skin problems such as atopic dermatitis, eczema and psoriasis (Bilandžić et al, 2013). This knowledge even dates back to ancient Egypt, when Queen Cleopatra bathed in mare's milk every day as part of her beauty ritual.

Some babies have atopic skin, i.e. skin with a tendency to dry, with a low fat content. The frequency of atopic dermatitis in children up to 2 years increases especially in developed or developing countries (due to industry factors and allergens from the air). This problem usually begins to improve around the age of 3 months and disappears up to the age of 2 years. It may return - usually this happens around the age of 5 years.

Skin diseases, such as psoriasis and eczema are best treated from the inside out, from the place of action, removing the cause, not the symptoms. These treatments from the inside out take longer in terms of the effects, compared to treatments using cortisone creams for external use, but longterm results are much healthier for the body. Cortisone topical treatments are most commonly prescribed for atopic dermatitis, but they only reduce the external symptoms and are very dangerous to health if used on long term basis. These topic treatments thin out the epidermis and their therapeutic effect wares out forcing the increase of the dose.

In atopic dermatitis concentration of EFA (essential fatty acids) decreases, even though it was recently established that there is no deficiency of linoleic acid in this eczema. In addition, the concentration of linoleic acid tends to rise, to lift into the blood, into the milk and into the fat tissues ofpatientswithatopiceczema(Orlandi et al., 2003). This indicates a low conversion of linoleic acid to alpha linoleic acid (ALA). The administration into the human diet of alpha linolenic acid is considered to make improvements in skin roughness and also in the catecholamine blood concentration (Olivry et al., 2001).

All these indicate that mare's milk is more similar to human milk than cow's milk (Godovac- 
Zimmermann et al., 1987; Businco et al., 2000; Horrobin, 2000) and more suitable for allergic children's diet as a substitute (Pagliarini et al., 1993; Horrobin, 2000) in treating dermatitis.

Immune system: horse milk offers a good opportunity for regulating and strengthening the immune system (Jirillo et al., 2010). The effect of horse milk can be explained by the high value of albumin and globulin (building materials for antibodies), minerals and high quality unsaturated fat acids.

Metabolism problems: mare's milk stimulates digestion, stimulates detoxification of the body and helps to create a strong internal cleansing, an internal purification.

Liver disease: in all liver diseases (from chronicle hepatitis (Zhaksylykova and Sharmanov, 1979) to fat metabolism disease, a low-fat, light food diet and absolute abstention from alcohol are essential. Horse milk is highly appropriate for this type of diet.

Atherosclerosis and Cholesterol - Raw horse milk and fermented derivatives are considered useful in the prevention of atherosclerosis (Chiofalo et al., 2006). They support a justified cholesterol level. Fat regime is the most important factor that influences the human condition, especially in cardiovascular diseases. Health quality would be better if we decreased fat in our diet, and if we changed the unsaturated fatty acids ratio. The high value of unsaturated and many saturated fat acids has an adjusting effect on a destroyed fat metabolism. Used regularly, it can decrease the cholesterol level of the blood. Upon comparing the cardiovascular status of ovo-lactovegetarians and vegans, it has been proven that while both are healthier than meat-eaters, vegans have better cardiovascular status than vegetarians who consume dairy cow products (Melby et al., 1989). Mare's milk apparently contains $\alpha$-linolenic (ALA) and linoleic (LA) acid amounts, which are called EFA (essential fatty acids) and traces of $\omega-3$ and $\omega-6$, higher than in cow's milk (Csapò et al., 1995), although many polyunsaturated fatty acid (LCPUFA) contents are limited. From $\alpha$ linolenic and eicosapentaenoic acid derive prostaglandins, like PGI, with vasodilatory effects, tromboxans, like TXA, with vasoconstrictive effects, and docosahexaenoic acid (DHA). From linoleic acid derive many other prostaglandis (PGI2) and tromboxans with different influences on the circulatory system (Gibney, 1993; Calder, 1996). Fat from cow's milk contains relatively high concentrations of saturated fats which have been implicated in heart diseases (Ney, 1991). Cow's milk fat has been identified as a cholesterolelevating fat, because it contains cholesterol and is primarily saturated (Franklin et al., 1999).

Muscles, Joints and Bones - Mare's milk is good for rigid muscles and joints, and takes care of the good structure and preservation of the bones.

Bowels and Stomach - It promotes the bowel functioning for a good metabolism; it also helps bad digestion, acid belching and inconveniences in the abdomen. Mare's milk is very useful for treating gastric ulcer and duodenal ulcers (Salhanov and Sarmanov, 1979).

Cancer - The functionality of horse milk on the immune system, the stimulation of all detoxification mechanisms of the body (liver, kidneys, intestines, sweat glands, etc.) and the effect on healthy blood texture, all of which benefit from horse milk, as does cancer therapy and cancer readjustment through its anti-tumoral activity (Mao et al. 2009). Besides a surgical treatment which is inevitable, with cancer disorders the application of irradiation therapy and chemotherapy are inevitable; therefore, significant attention should be paid to the physical condition of the patient. Cancer therapy attacks both the sick and the healthy cells of the patient (especially the cells of the hair roots, the guts, and the blood forming organs, the immune system and the skin). Because of that, during and after a series of irradiations and treatment with chemotherapy, the patient suffers loss of hair, intestinal problems, and a high degree of vulnerability for infectious diseases. The organism is barely able to protect itself against banal infections, let alone mobilizing its defence system in the battle against metastases (daughter cells) and the appearance of other tumours. The body affected by tumours (metastases) will also be affected by metabolism toxins released during the therapy and by the damaged detoxification mechanisms. To endure this phase better, to activate the immune system once again, to trigger the detoxification through liver, bowels, kidneys and skin anew and to give the patient new strength, horse milk (in milk, powder or capsule form) is strongly recommended (Uniacke-Lowe et al., 2010).

Mare's milk is also used to treat tuberculosis (Gilmutdinova et al., 2011), intestinal infections and anaemia (Uzakbaev and Mamyrbaeva, 2012). It 
has also been reported to accelerate post-surgical recovery (Zaripov and Kanareikina, 2013).

Horse milk is not a magic cure by which you can cure incurable ailments, but it has been reported to have a very good influence on health and to provide support in the battle against a diversity of different disorders.

\section{Cosmetics containing mare's milk}

Equine milk is used in cosmetology with very good results. Horse milk fat is considered an important ingredient in Mongolian cosmetics because of its high polyunsaturated fatty acid content (Temuujin et al., 2006). Milk proteins are active in skin hydration and skin ageing prevention (Cotte, 1991).

In this study, we have aimed to provide a hierarchy of cosmetics and dietary supplements containing mare's milk that exist on the market.

The first products are available on the market under the name of Equilac, and they are pioneers in this area, having been on the European market for merely 15 years. In 2009 they opened a unit in the USA as well.

Some of the products using horse milk as the principal active component that are currently available on the market include:

Equilac: Shampoo, Shower cream, Body cream, Soap, Hand cream, Horse milk capsules;

Paardenmelk de lage wierde: Horse milk Powder (freeze dried), Horse milk Capsules (freeze dried), Horse milk Soap, Horse milk Hand cream, Horse milk Lotion, Horse milk shampoo, Horse milk muscle balm;

Domaine de la Voie Lactée: Shampoo, Shower cream, Body cream, Soap, Hand cream;

Nature Progress: Shampoo, Shower cream, Body cream, Soap, Hand cream.

\section{CONCLUSIONS}

Compared to bovine milk, equine milk contains less fat, protein, and inorganic salts, but more lactose.

The microflora found in mare's milk consists mostly of species such as Lactobacillus delbrueckii ssp. bulgaricus, Lactococcus lactis ssp. lactis, Kluyveromyces fragilis, Saccharomyces unisporus, Bifidobacterium mongoliense sp. nov. , Lactobacillus casei Zhang.

Mare's milk is very similar to human milk, so it could be a very good alternative for cow's milk.
Milk allergy is considered to be an increasing problem in infancy so mare's milk would appear to be, on the whole, a more suitable nourishment than cow's milk.

Results presented in recent research in Europe have shown that horse milk is good for: skin diseases, general physical health, metabolism problems, immune system, stomach function, liver disease, muscles, joints and bones, cardiovascular diseases and cholesterol, cancer.

Horse milk fat is considered an important ingredient in Mongolian cosmetics because of its high polyunsaturated fatty acid content. Milk proteins are active in skin hydration and skin ageing prevention.

Horse milk-based cosmetic products are available on the market under different brands names, including: Equilac, Paardenmelk de lage wierde, Domaine de la Voie Lactee, Nature Progres.

\section{REFERENCES}

1. Abd El-Salam MH, Farag SI, El-Dein HF, Mahfouz MB, ElEtriby HM (1992). A comparative study on milk proteins of some mammals. Proceedings of 5th Egyptian Conference Dairy Science \& Technology, 281- 287, Egyptian Society of Dairy Science, Cairo, Egypt.

2. Adolphi B, Scholz-Ahrens K E, de Vrese M, Açil Y, Laue C, Schrezenmeir J (2009). Short-term effect of bedtime consumption of fermented milk supple-mented with calcium, inulin-type fructans and casein phosphopeptides on bone metabolism in healthy, postmenopausal women. European Journal of Nutrition, 48,45-53

3. Akai Tegin RA, Gonulalan Z (2014). All aspects of natural fermented products - koumiss. MANAS Journal of Engineering 2(1):23-34.

4. Alais C (1974). Science du lait. Principes des techniques laitières. 3ème édition. Paris, France: S.E.P.A.I.C.

5. Anderson R R (1991). Comparison of minerals in milk of four species. Comparative Biochemistry and Physiology, $100,1045-1048$.

6. Andersson I, Öste R (1995). Chapter 13: Nutritional quality of heat processed liquid milk. In P. F. Fox (Ed.), Heat-induced changes in milk (2nd Ed.) (279-307). Brussels: International Dairy Federation.

7. Barlowska J, Szwajowska M, Litwinczuk Z, Krol J (2011). Nutritional value and techological suitability of milk from various animal species used for dairy production. Comprehensive Reviews in food Science and Food Safety, 10, 291-302.

8. Batdorji B, Dalgalarrondo M, Choiset Y, Pedroche J, Metro F, Prevost H (2006). Purification and characterization of two bacteriocins produced by lactic acid bacteria isoleted from Mongolian airag. Journal of Applied Microbiology 101:837-848. 
9. Bilandžić N, Sedak $M$, Đokić $M$, Kolanović BS, Varenina I , Božić Đ, Končurat A. (2013). Concentrations of microelements $\mathrm{Al}, \mathrm{Co}, \mathrm{Cr}, \mathrm{Li}, \mathrm{Mo}, \mathrm{Ni}, \mathrm{Sb}$ and $\mathrm{Sr}$ in the milk of Croatian Coldblood mares. Mljekarstvo 63(3):150-15.

10. Boland MJ, Hill JP, Creamer LK (1992). Genetic manipulation of milk proteins and its consequences for the dairy industry. Australasian Biotechnology, 2, 355360.

11. Businco L, Giampietro PG, Lucenti P, Lucaroni F, Pini C, Di Felice G, Iacovacci P, Curadi C, Orlandi M (2000) Alergenicity of mare's milk in children with cow's milk alergy. Journal of Allergy and Clinical Immunology 105:1031-1034.

12. Businco L, Bellanti J (1993): Food allergy in childhood. Hypersensitivity to cow's milk allergens. Clinical and experimental Allergy 23:481-483.

13. Cashman K (2006). Milk minerals (including trace elements) and bone health. International Dairy Journal 16:1389-1398.

14. Čagalj M, Brezovečki A, Mikulec N, Antunac N (2014). Composition and properties of mare's milk of Croatian Coldblood horse breed. University of Zagreb, Croatia 64:311.

15. Chen Y, Wang Z, Chen X, Liu Y, Zhang H, Sun T (2010). Identification of angiotensine l-converting enzyme inhibitory peptides from koumiss, a traditional fermented mare's milk. Journal of Dairy Science 93:884-892.

16. Chiofalo B, Drogoul C, Salimei E (2006a). Other utilisation of mare's and ass's milk. EAAP Publ., 120:133-147.

17. Cotte, J. (1991). Le lait, una matière d'avenir pour la cosmétique.Lait 71:1213-1224.

18. Csapo J, Salamon Z, Loki K, Csapo-Kiss Z (2009). Composition of mare's colostrum and milk II. Protein content, amino acid composition and contents of macroand micro-elements. Acta Universitatis Sapientiae, Alimentaria 2 (1):133-148.

19. Curadi MC. Giampietro PG, Lucenti P, Orlandi M (2001). Use of mare milk in pediatric allergology. Proceedings of the Associazione Scientifica di Produzione animale XIV Congress, Firenze, 14:647-649.

20. D’Arval C (1912). Il latte nella produzione e nell'igiene dell'alimentazione. Milano. Italy. Antonio Vallardi Ed. (Chapter 2).

21. Del Piano M, Morelli L, Strozzi G ( 2006). Probiotics: from research to consumer Digestive and Liver Disease 38:248-255.

22. Dietschy JM, Turley SD (2004). Cholesterol metabolism in the central nervous system during early development and in the mature animal. Journal of Lipid Research, 45, 1375-1397.

23. Di Cagno R, Tamborrino A, Gallo G, Leone C, De Angelis M, Faccia M (2004). Uses of mare's milk in manufacture of fermented milk. International Dairy Journal 14:767-775.

24. Doreau M (1994). Le lait de jument et sa production: Particularites et facteurs de variation. Lait 74:401-418.

25. Doreau M, Boulot S (1989). Recent Knoledge on mare milk production: A review. Livestock Production Science 22:213-235.
26. Doreau M, Martin-Rosset W (2002). Dairy animals: horse. In H. Roginsky, J. W. Fuquay \& P. F. Fox (Eds.), Encyclopedia of dairy sciences (358-365). London, Amsterdam: Academic Press.

27. Drogoul C, Prevost H, Maubois J-L (1992). Le lait de juments un produit, une filiere a developper? Quoi de neuf en matiere d'etudes de recherches sur le cheval?, 18eme Journee d'Etude, CEREOPA, Paris, 37-51.

28. Fantuz F, Ferraro S, Todini L, Piloni R, Mariani P, Salimei E (2012). Donkey milk concentration of calcium, phosphorus, potassium, sodium and magnesium. International Dairy Journal 24:143-145.

29. Franklin ST, Martin KR, Baer RJ, Schingoethe DJ, Hippen AR (1999). Dietary Marine Algae (Schizochytrium sp.) increases concentrations of conjugated linoleic, docosahexaenoic and transvaccenic acids in milk of dairy cows. J Nutr 129(11):2048-2054.

30. Gaucheron F (2005). The minerals of milk. Reproduction Nutrition Development, 45,473-483.

31. German JB, Dillard CJ (2006). Composition, structure and absorption of milk lipids: a source of energy, fat-soluble nutrients and bioactive molecules. Critical Reviews in Food Science and Nutrition, 46, 57-92.

32. Gibney MJ (1993). Fish oils in human health. Recent advances in animal nutrition in Australia. DJ Farrell Ed., Univ. Of New England, Armidale, NS.W.

33. Gidding SS, Dennison BA, Birch LL, Daniels SR, Gilman MW, Lichtenstein AH (2006). Dietary recommendations for children and adolescents: a guide for practitioners. Pediatrics, 117, 544-559.

34. Godavac-Zimmermann J, Shaw D, Conti A, Mckenzie H (1987). Identification and the primary structure of equine $\alpha$-lactalbumin. Biol. Chem.. Hoppe Seyler 368:427-433.

35. Gopal PK, Gill HS (2000). Oligosaccharides and glycoconjugates in bovine milk and colostrum. Br J Nutr 84:69-74.

36. Guarner F, Schaafsma GJ (1998). Probiotics. Int. J. Food Microbiol. 39:237-238.

37. Guo Z, Wang J, Yan L, Liu X, zhang H (2009). In vitro comparison of probiotic properties of Lactobacillus casei Zhang, a potential new probiotic, with selected probiotic strains. Food Science and Techology 42:1640-1646.

38. Hambræus L (1994). Milk composition in animals and humans. Nutritional aspects. 1st world congress Dairy products in human health and nutrition, Madrid, 13-23.

39. Hoffman RM, Kronfeld DS, Herbein JH, Swecker WS, Cooper WL, Harris, PA (1998). Dietary carbohydrates and fat influence milk composition and fatty acid profile of mare's milk. The Journal of Nutrition, 128, 2708S-2711S.

40. Horrobin DF (2000). Essential fatty acid metabolism and its modification in atopic eczema. Am. J. Clin. Nutr. 71 (1):367-372.

41. Jainudeen M R (2002). Buffalo husbandry. In H. Roginsky, J. W. Fuquay, P. F. Fox

42. (Eds.), Encyclopedia of dairy sciences (pp. 186-193). London, Amsterdam: Academic Pres.

43. Jirillo E, D’Alessandro AG, Amati L, Jirillo F, Pugliese V, Martemucci G (2010).Modulation of human aged immune 
response by donkey milk intake. 61st Annual Meeting of Animal Production, , Heraklion, Crete Island, Greece.

44. Kailasapathy K, Rybka S (1997). L. Acidophilus and Bifidobacterium spp. their therapeutic potential and survival in yogurt. Aus J Dairy Technol 52:28-35.

45. Kalliala H, Seleste E, Hallman N (1951). On the use of mare's milk in infant feeding. Acta paediatrica 40:94-117.

46. Kharitonova I (1978). Fatty acids and phospholipids in mare's milk. Konevodstvo i Konnyi Sport, 12, 24 (Abstract).

47. Kunz C, Rudloff S (2006). Health promoting aspects of milk oligosaccharides. International Dairy Journal, 16, 1341-1346.

48. Kunz C, Rodriguez-Palmero M, Koletzko B, Jensen R (1999). Nutritional and biochemical properties of human milk, part I: General aspects, proteins, and carbohydrates. Clinics in Perinatology 26:307-333.

49. Macharadze DS (2007). Atopic dermatitis in children: A Guide. Moscow, Geotar Media.

50. Malacarne M, Martuzzi F, Summer A,Mariani P (2002). Protein and fat Composition of mare's milk: some nutritional remarks wirh reference to human and cow's milk. International Dairy Journal 12:869-877.

51. Mao X, Gu J, Xu YSS, Zhang X, Yang H, Ren F (2009). Antiproliferative and anti-tumor effect of active components in equine milk. International Daidy Journal 19:703-708.

52. Marconi F, Panfili G (1998). Chemical composition and nutritional properties of commercial products of mare milk powder. Journal of food composition and analysis 11:178-187.

53. Mariani P, Martuzzi F, Catalano AL (1993). Composizione e proprieta fisico-chimiche del latte di cavalla: Variazione dei costituenti azotati e minerali nel corso della lattazione. Annali Facolta di Medicina Veterinaria, Universita di Parma, 13, 43-58.

54. Martinez-Ferez A, Rudloff S, Guadix A, Henkel CA, Pohlentz G, Boza JJ, et al.

55. (2006). Goats'milk as a natural source of lactosee derived oligosaccharides: isolation by membrane technology. International Dairy Journal, 16, 173-181.

56. Martuzzi F, Summer A, Catalano AL, Barbacini S, Mariani P (1998). Il contenuto in acidi Grassi polinsaturati del grasso del latte di cavalla prodotto nelle prime settimane di lattazione. Proceedings of Convegno Nazionale Societa italiana Scienze Veterinarie 52:537-538.

57. Mehra R, Kelly P (2006). Milk oligosaccharides: structural and technological aspects. International Dairy Journal, 16, 1334-1340.

58. Melby CL, Toohey ML, Cebrick J (1994). Blood pressure and blood lipids among vegetarian, semivegetarian and nonvegetarian African americans. Am J Clin Nutr 59(1):103-9.

59. Naert L. Vandevyvere B, Verhoeven G, Duchateau L, De Smet S, Coopman F (2013). Assessing heterogeneity of the composition of mare's milk in Flanders. Vlaams Diergeneeskunding Tijdschrift 82:23-30.

60. Nakamura T,Amikawa S, Harada T,Saito T,Arai I, Urashima $\mathrm{T}$ (2001). Occurrence of an unusual phosphorylated
$\mathrm{N}$-acetyllactosamine in horse colostrum. Biochimica et Biophysica Acta, 1525,13-18.

61. Ney DM (1991). Potential for enhancing the nutritional properties of milk fat. J. Dairy Sci. 74:4002-4012.

62. Orlandi M, Goracci J, Curadi M (2003). Fat composition of mare's milk with reference to human nutrition. Annali della Facolta di Medicina veterinaria 56:97-105.

63. Olivry T, Marsella R, Hillier A (2001). The ACVD task force on canine atopic dermatitis: are essential fatty acids effective? Vet. Immunol. Immunopathol., 20, 81(3-4): 347362.

64. Park YW, Juarez M, Ramos M, Haenlein GFW (2007). Physico-chemical characteristics of goat and sheep milk. Small Ruminant Research 68:88-113.

65. Pietrzak-Fiecko R, Tomczynski R, Swistowska A, Borejszo Z, Kokoszko E, Smoczynska K (2013). Effect of lactation period on the fatty acid composition in mare's milk from different breeds. Archiv Tierzuch 56. 33:335-343.

66. Potočnik K, Gantner V, Kuterovac K, Cividini A (2011). Mare's milk: composition and protein fraction in comparison with different milk species. Mljekarstvo 61 (2):107-113.

67. Pulina G, Nudda A (2002). Milk production. In G. Pulina (Ed.), Bologna, Italy: Avenue Media. Dairy sheep feeding and nutrition 11-27.

68. Salamon RV, Salamon Sz, Csapo-Kiss Zs, Csapo J (2009). Comosition of mare's colostrums and milk I. Fat content, fatty acid composition and vitamin contents. Alimentaria 2:119-131.

69. Salhanov BA, Sharmanov TSh (1979). Treatment of patients with gastric ulcer and duodenal ulcer with the inclusion in the diet of whole camel and mare's milk. Dissertation of the candidate of medical sciences, Bishkek.

70. Salimei E, Fantuz F (2012). Equid milk for human consumption. International dairy Journal 24:130-142.

71. Salimei E, Fantuz F, Coppola R, Chifalo B, Polidori P, Varisco $\mathrm{G}$ (2004). Composition and characteristics of ass's milk. Animal Research, 53, 63-78.

72. Schaafsma G (1989). Effects of heat treatment on the nutritional value of milk. Bulletin of the International Dairy Federation, 238,68-70.

73. Schanler RJ (2011). Outcomes of human milk-fed premature infants. Seminars in Perinatology, 35, 29-33.

74. Sheng Q,Fang X (2009). Bioactive Components in Mare milk. In. Y.W.Park (Eds.), Bioactive Components in Milk and Dairy Products. Wiley-Blackwell, Ames, Iowa, USA 195-213.

75. Solaroli G, Pagliarini E, Peri C (1993). Composition and nutritional quality of mare's milk. Italian Journal of Food Science 5:3-10.

76. Summer A, Sabbioni A, Formaggioni P, Mariani P (2004). Trend in ash and mineral element content of milk from Haflinger nursing mares throughout sixlactation months. Livestock Production Science 88:55-62.

77. Sundar S, Chakravarty J (2010). Antimony toxicity. International Journal of Environmental Research and public Health 7 (12):4267-4277. 
78. Temuujin J, Senna M, Jadambaa T S, Burmaa D, Erdenechimeg S, Amarsanaa J (2006). Characterization of nanoporous materials prepared from mont-morillonite clay and its application to the decolorization of mare's milk oil. Journal of Porous Mater 13:49-53.

79. Uniacke-Lowe T, Huppertz T, Fox PF (2010).Equine milk proteins: chemistry, structure and nutritional significance. International Dairy Journal 20:609-629.

80. Uzakbaev KA, Mamyrbaeva TT.(2012). Mare's milk and koumiss. Bishkek: Nur-As.

81. Watanabe K, Fujimoto J, Sasamoto M, Dugersen J, Tumursuh K, Demberel S (2008). Diversity of lactic acid bacteria and yeast in Airag and Tarag, traditional fermented milk products of Mongolia. World Journal of Microbiology and Biotechnology 24:1313-1325.

82. Watanabe K, Makino H, Sasamoto M, Kudo Y, fujimoto J, Demberel S (2009). Bifidobacterium mongoliense sp. Nov., from airag, a traditional fermented mare's milk product from Mongolia, International Journal of Systematic and Evolutionary Microbiology 59:1535-1540.

83. Welsch U, Buchheim W, Schumacher U, Schinko I, Patton S(1988). Structural, histochemical and biochemical observations on horse milk-fat-globule membranes and casein micelles. Histochemistry, 88, 357-365.

84. Zaripov RR, Kanareikina SG (2013). The study of the quality of dry mare's milk. Materialy VI Vcerossiyskoy Konferensiyi Molodyh Uchenyh 81-86

85. Zhaksylykova, RD, Sharmanov T Sh (1979). The use of whole camel and mare's milk in the diet therapy of patients with chronic hepatitis. Dissertation of the candidate of medical sciences, Bishkek

86. Zhang Y, Du RT, HE Qiu-Wen, Li H, Zhang HP (2012). Effect of Lactobacillus casei Zhang administration on liver lipids metabolism of high-fat diet induced hypercholesterolemia rats 45:943-950. 